\title{
Reliability of in-situ diagnosis in external wall renders
}

\author{
I. Flores-Colen ${ }^{\mathrm{a}, *}$, J. de Brito ${ }^{\mathrm{a}}$, V.P. de Freitas ${ }^{\mathrm{b}}$, A. Hawreen ${ }^{\mathrm{c}, \mathrm{d}}$ \\ ${ }^{a}$ CERIS, DECivil, Instituto Superior Técnico, Universidade de Lisboa, Av. Rovisco Pais, Lisbon 1049-001, Portugal \\ ${ }^{\mathrm{b}}$ CONSTRUCT-LFC, FEUP, University of Porto, Rua Dr. Roberto Frias, Porto 4200-465, Portugal \\ ${ }^{\mathrm{c}}$ Department of Civil Engineering, Technical Engineering College, Erbil Polytechnic University, Kurdistan Region, Erbil, Iraq \\ ${ }^{\mathrm{d}}$ Scientific Research and Development Center, Nawroz University, Duhok, Kurdistan-Region, Iraq
}

\section{H I G H L I G H T S}

- Reliability indicators are proposed based on experimental data.

- Reliability indicators application helps the evaluation of in-service performance of renders.

- An overall reliability indicator has been proposed.

\section{A R T I C L E I N F O}

\section{Article history:}

Received 28 September 2019

Received in revised form 24 March 2020

Accepted 5 April 2020

Available online 22 April 2020

\section{Keywords:}

External wall

Render

In-service performance

Inspection

On-site tests

\begin{abstract}
A B S T R A C T
This study focuses on the reliability of in-situ diagnosis performed on external rendered façades. This analysis was based on a set of parameters drawn from different visual observation, in-situ and laboratory testing techniques. The results were collected based on the previous inspections of 98 rendered façades of buildings and individual testing walls with different components, ages and degradation types. For that purpose, a reliability indicator was proposed and applied for better results interpretation of multiple testing techniques. In each case study, the parameters with higher reliability are defined. The final reliability indicator was established based on the average of three partial indicators, namely a reliability indicator for the established base criteria' uncertainty in laboratory testing (reference reliability indicator); a reliability indicator for the assessment techniques' uncertainty (verification method reliability indicator); and a reliability indicator for the results' uncertainty (number of the tests and their accuracy; reliability indicator of results obtained in-service). The reference parameters for each testing technique were synthesised. The relevant aspects, such as uncertainty associated with the reference parameter and type of verification method (quantitative, qualitative, and intervals), were defined. The analysis of the relationships between the parameters (exemplified for mechanical properties) and their correlation coefficients were assessed. Selection matrices were proposed that qualitatively identify the set of parameters that contribute to indirectly analyse the characteristics and performance relevant to the behaviour of the renders applied on façades.
\end{abstract}

(c) 2020 Elsevier Ltd. All rights reserved.

\section{Introduction}

External rendered façades are important elements of the building and significantly contribute to its in-service performance by playing a key role on the interior hygrothermal conditions [1]. In general, the main required render characteristics include adequate elasticity to prevent the formation of cracks due to movements, sufficient adhesion to the support without blistering, resistance to various climatic agents, suitable water vapour permeability in

\footnotetext{
* Corresponding author.

E-mail addresses: ines.flores.colen@tecnico.ulisboa.pt (I. Flores-Colen), jb@civil. ist.utl.pt (J. de Brito), vpfreita@fe.up.pt (V.P. de Freitas), hawreen.a@gmail.com (A. Hawreen).
}

order to have a good in-service behaviour during the wetting and drying processes, and mechanical strength [2-7].

The façades are subject to a degradation process over time, which can decrease their service life [8-10]. The main degradation agents against external façades include solar radiation, temperature, water, wind, chemical and biological agents, and human action [11-17]. Thus, in-situ testing is essential for the degradation level evaluation in order to take maintenance actions to ensure good overall performance throughout the façade's life cycle [18-28]. However, the in-depth study of façades' in-service performance is complex. This is because it presents a great variability during the life cycle of the building, associated to several factors, including the design decisions, constructive processes, applied 
materials' characteristics, life cycle duration of each element, and testing techniques' variability.

The usefulness of the information collected on site and the reliability of the verification methods used are decisive factors for the success of the inspection diagnosis and with consequent recommendation of adequate maintenance actions [29,30]. The earlier analysis of the various verification methods allows understanding the importance of real-time evaluations to increase information on in-service performance and the actual capabilities of building elements [31-34]. Therefore, this study focuses on the reliability of in-situ diagnosis on external wall renders, based on several insitu methods [35]: visual observation; expedient techniques; insitu tests, laboratory tests with samples collected in the field. Fig. 1 simply shows the proposed steps to define reliability of each mechanical and physical-chemical testing techniques.

\section{Proposal of the reliability indicators}

The proposal of the reliability indicators is based on the PhD thesis of the first author. In this study several experimental programs were carried out for 4 years, and 98 rendered façades were tested on 42 buildings (Tables 1 and 2), based on observation and measurement parameters The building façades were chosen randomly and had various render solutions (conventional renders with paint; coloured pre-dosed mortars) and substrates (concrete blocks, hollow brick leaves with or without an air cavity, stone masonry walls). The discussion of the results is not within the scope of this paper as some of them have been already published and discussed into detail for several techniques [19,23,35,36].

The combined analysis of multiple parameters may increase the knowledge about in-service physical (moisture resistance, water permeability resistance, and hygrothermal resistance), chemical (chemical resistance, biological resistance) and mechanical properties (adhesion to the wall support, cohesive strength, surface resistance, and deformation capacity) of rendered walls.

Therefore, three partial reliability indicators were proposed to better interpret the results of multiple in-situ testing techniques. These indicators were applied to define the parameters with higher reliability in each case study. The main reliability indicator was evaluated from the three partial reliability indicators, as described below:

- Reference reliability indicator (RRI) - uncertainty (expressed as a percentage) associated with the proposed mean value for the reference, from the laboratory tests or from the relationships between parameters;

- Verification method reliability indicator (VMRI) - includes four indexes that contribute to the classification: $\mathrm{I}_{\mathrm{f} 2}$ - accuracy of the verification method (quantitative, qualitative or a range of values); $I_{f 3}$ - contribution of the method for the identification of the two pre-dosed or conventional mortar groups; $\mathrm{I}_{\mathrm{f} 4}$ - sensitivity of the method to in-situ factors (surface moisture, type of finishing and support, among others); $\mathrm{I}_{\mathrm{f} 5}$ - contribution of the method to the characterization of anomalies related to the mechanical behaviour (cracking, loss of cohesion and detachments);

- Reliability indicator of results obtained in-service (RIRS) - it characterizes the greater or lesser variability of the results obtained in the case studies analysed, through two indexes: $\mathrm{I}_{\mathrm{f} 6}$ - variation coefficient of the results and $\mathrm{I}_{\mathrm{f} 7}$ - number of measurements; in these two indexes, the analysis can be done in one or for all the surfaces of each case study.

The classification of the global reliability indicator (RI) for each measurement parameter ranges from 1 to 5 and is calculated by Eq. (1) (arithmetic mean of the previous indicators).

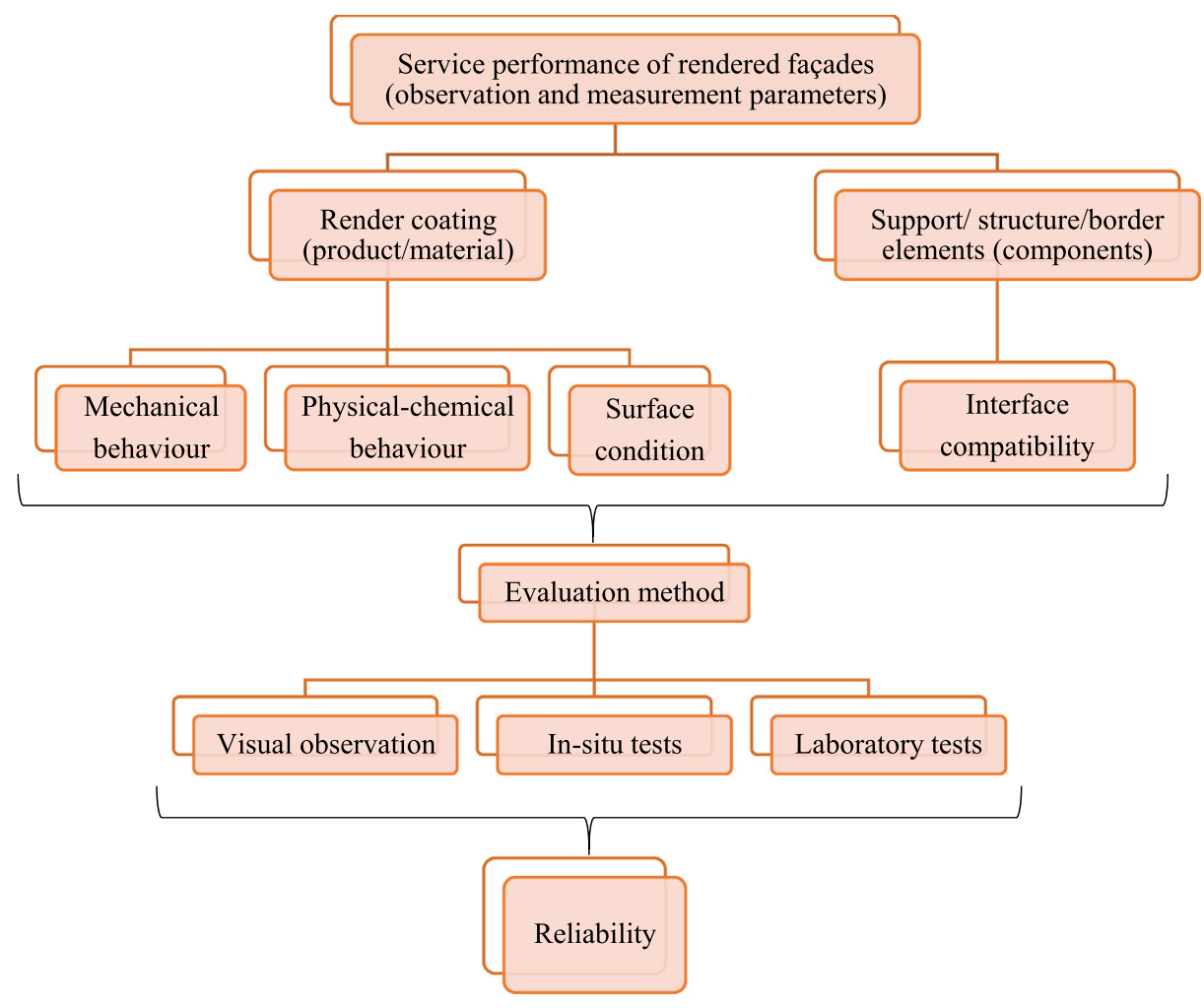

Fig. 1. Methodology to study reliability based on several experimental methods. 
Table 1

Observation and measurement parameters with expedient techniques in each case study.

\begin{tabular}{|c|c|c|c|c|c|c|c|c|c|c|c|}
\hline Verification methods & $\begin{array}{l}\text { Parameters of observation and measurement } \\
\text { in-service, or auxiliary activities }\end{array}$ & CS1 & $\mathrm{CS} 2$ & CS3 & CS4 & CS5 & CS6 & $\begin{array}{l}\text { CS7- } \\
\text { CS8 }\end{array}$ & $\begin{array}{l}\text { CS11- } \\
\text { CS13 }\end{array}$ & $\begin{array}{l}\text { CS14- } \\
\text { CS40 }\end{array}$ & CS42 \\
\hline \multicolumn{12}{|l|}{ Observation } \\
\hline \multirow{4}{*}{$\begin{array}{l}\text { Visual observation with photographic record } \\
\text { and completion of inspection form }\end{array}$} & Stains & $\mathrm{X}$ & $\mathrm{X}$ & $\mathrm{X}$ & $\mathrm{X}$ & $\mathrm{X}$ & $\mathrm{X}$ & $\mathrm{X}$ & $\mathrm{X}$ & $\mathrm{X}$ & $\mathrm{X}$ \\
\hline & Cracking & $\mathrm{X}$ & $\mathrm{X}$ & $\mathrm{X}$ & $\mathrm{X}$ & $\mathrm{X}$ & $\mathrm{X}$ & $\mathrm{X}$ & $\mathrm{X}$ & $\mathrm{X}$ & $\mathrm{X}$ \\
\hline & Detachments & $\mathrm{X}$ & $\mathrm{X}$ & $\mathrm{X}$ & $\mathrm{X}$ & $\mathrm{X}$ & $\mathrm{X}$ & $\mathrm{X}$ & $\mathrm{X}$ & $\mathrm{X}$ & $\mathrm{X}$ \\
\hline & Loss of cohesion & $\mathrm{X}$ & $\mathrm{X}$ & $\mathrm{X}$ & $\mathrm{X}$ & $\mathrm{X}$ & $\mathrm{X}$ & $\mathrm{X}$ & $\mathrm{X}$ & $\mathrm{X}$ & $\mathrm{X}$ \\
\hline $\begin{array}{l}\text { Visual observation and recording (anomaly } \\
\text { causes) }\end{array}$ & Interface incompatibility & $\mathrm{X}$ & $\mathrm{X}$ & $\mathrm{X}$ & $\mathrm{X}$ & $\mathrm{X}$ & $\mathrm{X}$ & $\mathrm{X}$ & $\mathrm{X}$ & $\mathrm{X}$ & $\mathrm{X}$ \\
\hline \multicolumn{12}{|l|}{ Means of auxiliaries } \\
\hline Camera & Photos & $\mathrm{X}$ & $\mathrm{X}$ & $\mathrm{X}$ & $\mathrm{X}$ & $\mathrm{X}$ & $\mathrm{X}$ & $\mathrm{X}$ & $\mathrm{X}$ & $\mathrm{X}$ & $\mathrm{X}$ \\
\hline Binoculars & Long-distance observation & $\mathrm{X}$ & - & $\mathrm{X}$ & - & $\mathrm{X}$ & $\mathrm{X}$ & - & - & $\mathrm{X}$ & $\mathrm{X}$ \\
\hline Magnifying glass & Short-distance observation & $\mathrm{X}$ & - & $\mathrm{X}$ & - & $\mathrm{X}$ & $\mathrm{X}$ & - & - & - & - \\
\hline $\begin{array}{l}\text { Optical microscope (with/without } \\
\text { measuring scale) }\end{array}$ & Microscopic observation & $\mathrm{X}$ & - & $\mathrm{X}$ & - & $\mathrm{X}$ & - & - & $\mathrm{X}$ & $\mathrm{X}$ & - \\
\hline NCS colour spectrum & Identification of chromatic scales & $\mathrm{X}$ & - & - & - & $\mathrm{X}$ & - & - & - & - & - \\
\hline Crack comparator & Average crack width & $\mathrm{X}$ & $\mathrm{X}$ & $\mathrm{X}$ & $\mathrm{X}$ & $\mathrm{X}$ & $\mathrm{X}$ & - & $\mathrm{X}$ & $\mathrm{X}$ & $\mathrm{X}$ \\
\hline $2 \mathrm{~m}$ ruler & Plan & - & $\mathrm{X}$ & - & - & - & - & - & - & - & - \\
\hline Tape measure/level/rulers & - & $\mathrm{X}$ & $\mathrm{X}$ & $\mathrm{X}$ & - & $\mathrm{X}$ & $\mathrm{X}$ & - & $\mathrm{X}$ & $\mathrm{X}$ & - \\
\hline Rubber hammer & Percussion and sound evaluation & $\mathrm{X}$ & $\mathrm{X}$ & $\mathrm{X}$ & - & $\mathrm{X}$ & $\mathrm{X}$ & $\mathrm{X}$ & $\mathrm{X}$ & $\mathrm{X}$ & - \\
\hline Water sprayer container & $\begin{array}{l}\text { Surface wetting for the incidence qualitative } \\
\text { evaluation of cracks and pulverulescence }\end{array}$ & $\mathrm{X}$ & $\mathrm{X}$ & - & $\mathrm{X}$ & $\mathrm{X}$ & - & - & - & - & - \\
\hline Phenolphthalein solution & Qualitative evaluation of carbonation & $\mathrm{X}$ & $\mathrm{X}$ & - & - & - & - & - & - & - & - \\
\hline Low speed drill/hammer with metal spatula & Collection of small samples or in powder form & $\mathrm{X}$ & $\mathrm{X}$ & - & - & $\mathrm{X}$ & $\mathrm{X}$ & - & - & - & - \\
\hline Sample bags/labels & Storage and identification of samples & $\mathrm{X}$ & $\mathrm{X}$ & - & $\mathrm{X}$ & $\mathrm{X}$ & $\mathrm{X}$ & $\mathrm{X}$ & - & - & - \\
\hline Compass & Parameter orientation & $\mathrm{X}$ & $\mathrm{X}$ & $\mathrm{X}$ & $\mathrm{X}$ & $\mathrm{X}$ & $\mathrm{X}$ & $\mathrm{X}$ & $\mathrm{X}$ & $\mathrm{X}$ & - \\
\hline Rugosimeter & Roughness measurement & $\mathrm{X}$ & $\mathrm{X}$ & - & - & - & - & - & - & - & - \\
\hline
\end{tabular}

Case studies CS9, CS10 and CS41 were not inspected under this study; the information used is the result of complaint procedures and was provided by a manufacturer.

Table 2

Measurement parameters verified with the in-situ and laboratory tests carried out in each case study.

\begin{tabular}{|c|c|c|c|c|c|c|c|c|c|c|c|c|c|}
\hline Verification methods & $\begin{array}{l}\text { Measurement } \\
\text { parameters }\end{array}$ & CS1 & CS2 & CS3 & CS4 & CS5 & CS6 & $\begin{array}{l}\text { CS7 } \\
\text { CS8 }\end{array}$ & $\begin{array}{l}\text { CS9 } \\
\text { CS10 }\end{array}$ & $\begin{array}{l}\text { CS11- } \\
\text { CS13 }\end{array}$ & $\begin{array}{l}\text { CS14- } \\
\text { CS39 }\end{array}$ & CS40 & CS41 \\
\hline \multicolumn{14}{|l|}{ In-situ techniques } \\
\hline Pull-off & $\mathrm{T}_{\mathrm{p}} ; \mathrm{C}_{\mathrm{s}}^{\mathrm{tp}}$ & $\mathrm{X}$ & $\mathrm{X}$ & - & $\mathrm{X}$ & $\mathrm{X}$ & $\mathrm{X}$ & $\mathrm{X}$ & - & - & - & - & - \\
\hline Martinet Baronnie & $\emptyset_{\text {core }} ; \mathrm{I}_{1}^{\mathrm{j}}$ & $\mathrm{X}$ & $\mathrm{X}$ & - & - & $\mathrm{X}$ & $\mathrm{X}$ & - & - & - & - & - & - \\
\hline \multirow[t]{3}{*}{ Pendulum hammer } & $\mathrm{PI}^{\mathrm{PT}}$ & $\mathrm{X}$ & $\mathrm{X}$ & - & - & - & - & - & - & $\mathrm{X}$ & - & - & - \\
\hline & $\mathrm{PI}^{\mathrm{P}}$ & $\mathrm{X}$ & $\mathrm{X}$ & $\mathrm{X}$ & & $\mathrm{X}$ & $\mathrm{x}$ & - & - & - & $\mathrm{X}$ & $\mathrm{X}$ & \\
\hline & $\mathrm{PI}^{\mathrm{N}}$ & $\mathrm{X}$ & - & $\mathrm{X}$ & & $\mathrm{X}$ & - & - & - & $\mathrm{X}$ & $\mathrm{X}$ & $\mathrm{X}$ & \\
\hline Ultrasound pulse velocity & $\mathrm{V}_{\mathrm{ap}}$ & $\mathrm{X}$ & $\mathrm{X}$ & - & $\mathrm{X}$ & $\mathrm{X}$ & $\mathrm{X}$ & - & - & $\mathrm{X}$ & - & - & - \\
\hline Karsten tube & $A_{l p}$ & $\mathrm{X}$ & $\mathrm{X}$ & $\mathrm{X}$ & $\mathrm{X}$ & $\mathrm{X}$ & $\mathrm{X}$ & - & - & - & - & $\mathrm{X}$ & - \\
\hline Moisture meter & $\mathrm{H}_{\text {sur }}$ & $\mathrm{X}$ & $\mathrm{X}$ & $\mathrm{X}$ & - & $\mathrm{X}$ & $\mathrm{X}$ & - & - & - & $\mathrm{X}$ & $\mathrm{X}$ & - \\
\hline Radiation pyrometer or infrared thermometer & $\mathrm{T}_{\text {sur }}$ & $\mathrm{X}$ & $\mathrm{x}$ & $\mathrm{X}$ & - & $\mathrm{X}$ & $\mathrm{X}$ & - & - & - & - & $\mathrm{X}$ & - \\
\hline Field kit & {$\left[\mathrm{Cl}^{-}\right] ;\left[\mathrm{NO}_{3}^{-}\right] ;\left[\mathrm{SO}_{4}^{2-}\right]$} & $\mathrm{X}$ & $\mathrm{X}$ & - & $\mathrm{X}$ & $\mathrm{X}$ & $\mathrm{X}$ & - & - & - & - & - & - \\
\hline Colorimetric tapes & {$\left[\mathrm{Cl}^{-}\right] ;\left[\mathrm{NO}_{3}^{-}\right] ;\left[\mathrm{SO}_{4}^{2-}\right]$} & $\mathrm{X}$ & $\mathrm{X}$ & - & - & - & $\mathrm{X}$ & - & - & - & $\mathrm{X}$ & - & - \\
\hline Portable meter & $\mathrm{pH}$; Cond.; TDS & $\mathrm{X}$ & - & - & $\mathrm{X}$ & - & - & - & - & - & - & - & - \\
\hline Rugosimeter & $\Delta_{\mathrm{a}}$ & $\mathrm{X}$ & - & - & - & - & - & - & - & - & - & - & - \\
\hline \multicolumn{14}{|l|}{ Laboratory techniques } \\
\hline Capillary absorption test & $\mathrm{C}^{\mathrm{ad}}$ & $\mathrm{X}$ & $\mathrm{X}$ & - & $\mathrm{X}$ & $\mathrm{X}$ & $\mathrm{X}$ & - & $\mathrm{X}$ & - & - & - & $\mathrm{X}$ \\
\hline Compression test & $\mathrm{C}_{s}^{\mathrm{ad}}$ & $\mathrm{X}$ & $\mathrm{X}$ & - & $\mathrm{X}$ & $\mathrm{X}$ & $\mathrm{X}$ & - & $\mathrm{X}$ & - & - & - & $\mathrm{X}$ \\
\hline Porosity test & $\mathrm{P}_{\mathrm{ap}}$ & $\mathrm{X}$ & $\mathrm{X}$ & - & - & $\mathrm{X}$ & $\mathrm{X}$ & - & $\mathrm{X}$ & - & - & - & $\mathrm{X}$ \\
\hline $\begin{array}{l}\text { Apparent bulk density or geometric } \\
\text { measurement }\end{array}$ & $\mathrm{D}_{\mathrm{ap}}^{\mathrm{GP}} ; \mathrm{D}_{\mathrm{ap}}^{\mathrm{AP}}$ & $\mathrm{X}$ & $\mathrm{X}$ & - & - & $\mathrm{X}$ & $\mathrm{X}$ & - & $\mathrm{X}$ & - & - & - & $\mathrm{x}$ \\
\hline Drying index & $\mathrm{D}_{\mathrm{I}}$ & $\mathrm{X}$ & $\mathrm{X}$ & - & - & $\mathrm{X}$ & $\mathrm{X}$ & - & $\mathrm{x}$ & - & - & - & $\mathrm{X}$ \\
\hline
\end{tabular}

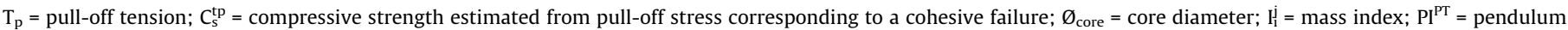

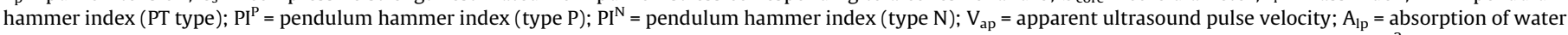

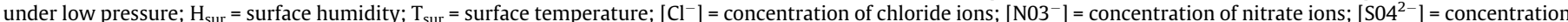

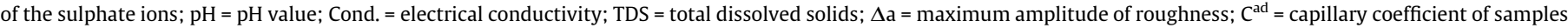

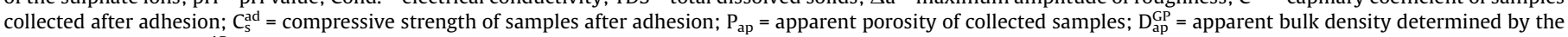
geometric principle; $\mathrm{D}_{\mathrm{ap}}^{\mathrm{AP}}=$ apparent bulk density determined by the Archimedes principle; $\mathrm{D}_{\mathrm{I}}=$ drying of samples collected after capillary absorption test.

$R I=(B R I+V M R I+R I R S) / 3$

where:

$\mathrm{RRI}=\mathrm{I}_{\mathrm{f} 1}=$ reliability of the reference parameter $(1 \leq \mathrm{RRI} \leq 5)$;

VMRI $=\left(\mathrm{I}_{\mathrm{f} 2} * \mathrm{I}_{\mathrm{f} 3} * \mathrm{I}_{\mathrm{f} 4} * \mathrm{I}_{\mathrm{f} 5}\right)^{1 / 4}=$ reliability of the verification method $(1 \leq \mathrm{VMRI} \leq 5)$;

RIRS $=\left(\mathrm{I}_{\mathrm{f} 6} * \mathrm{I}_{\mathrm{f} 7}\right)^{1 / 2}=$ reliability of the results obtained in-service $(1 \leq$ RIRS $\leq 5)$.

\section{Application of the reliability indicators proposal}

\subsection{Base considerations}

The explanation of the methodology will focus only on mechanical parameters to reduce the length of the paper. The analysis of the relationships between the mechanical parameters and their 
correlation coefficients is summarized in Table 3. It is concluded that most of the established relationships led to low correlation coefficients with results obtained in-service. Several factors may justify these results: a great diversity of case studies in terms of renders applied and supports; few results in some cases (not all parameters were studied for the 98 rendered façades); influence of anomalies in one or both parameters under analysis. However, other relationships among the mechanical parameters led to good correlation coefficients $\left(\mathrm{R}^{2}>0.60\right)$, such as:

- The relationship between pull-off tension $\left(T_{p}\right)$ and compressive strength extrapolated from the values of cohesive rupture $\left(\mathrm{C}_{\mathrm{s}}^{\mathrm{tp}}\right)$ (related to the pure tensile strength of the material);

- The relationship between ultrasound pulse velocity $\left(\mathrm{V}_{\mathrm{ap}}\right)$ and the core diameter $\left(\emptyset_{\text {core }}\right.$ ) with the compactness of the mortars (translated by the apparent density, $\mathrm{D}_{\mathrm{ap}}$ );

- The relation of the pendulum hammer index of the PT type $\left(\mathrm{PI}^{\mathrm{PT}}\right)$ with the ultrasound pulse velocity, impact diameter, bulk density and apparent porosity $\left(\mathrm{P}_{\mathrm{ap}}\right)$. In other words, this parameter is also influenced by the surface strength, compactness and internal resistance/homogeneity of the applied render. Through these relationships and the reference proposed parameters, it is possible to propose a reference limit for the pendulum hammer index (taking into account the in-situ conditions) equivalent to $75 \pm 7$ (Table 5), that distinguish more compact renders (e.g. conventional cement-based renders) than the other ones.

Based on the analysis of test results from Table 2, the reference parameters for each mechanical testing technique were synthesised (Table 4). The reference limit divides the two main groups of cementitious mortars: pre-dosed renders (group I) and conventional renders (group II). Some pre-dosed renders appear with mechanical characteristics similar to conventional renders, depending on the manufacturer's formulation. The minimum or maximum limits depend on the group of renders. Table 4 also summarizes some relevant aspects, such as: uncertainty associated with the reference parameter (determined by crossing several parameters or taking into account twice the standard deviation) and type of verification method (according to [37]): quantitative (when it is possible to compare with reference values); qualitative (it allows comparative results between them) and intervals (when results are provided in the form of interval or scales).

The previously discussed mechanical parameters were used as the base for the mean results analysis obtained for the various case studies. In this analysis, scales were assigned with four colours to synthesize the parameters' proximity to the limits and established reference parameters (Table 5):

- The green colour represents the results obtained in accordance with the reference parameter and maximum and minimum limits for each group of mortar;

- The yellow colour shows similar results to the green colour, but it is not expected for this type of product (being above or below), and is in principle favourable. For example, the apparent bulk values in CS1 are above the value predicted for group I in pre-dosed mortars;

- The orange colour represents results near (above or below) the reference limit, minimum or maximum, being unfavourable. For example, apparent porosity values in CS1 are high, being near the allowed upper limit;

- The results in the red colour section do not verify the proposed minimum or maximum limits.

The remaining cases that were not included in Table 5 fall into one of the following cases: it was not possible to compare the results with the reference parameters (for example, in case studies where only the pendulum hammer type $\mathrm{N}$ was used) or no tests were performed.

Table 3

Comparison of dependence relationships between mechanical measurement parameters, established in the laboratory and verified in-situ.

\begin{tabular}{|c|c|c|c|}
\hline Parameters & & $\begin{array}{l}\text { Relations between the laboratory } \\
\text { testing results with } \mathrm{R}^{2}>0.6\end{array}$ & $\begin{array}{l}\text { Relations between the field } \\
\text { testing results }\end{array}$ \\
\hline $\mathrm{D}_{\mathrm{ap}}^{\mathrm{GP}}$ or $\mathrm{D}_{\mathrm{ap}}^{\mathrm{AP}}$ & $\begin{array}{l}P_{a p} \\
C_{s}^{a d} \\
C_{s}^{t p}\end{array}$ & $\begin{array}{l}\text { linear } \\
\text { power (with } C_{s} \text { ) } \\
\text { power }\left(\text { with } C_{s} \text { ) }\right.\end{array}$ & $\begin{array}{l}\mathrm{R}^{2} \leq 0.32 \\
\mathrm{R}^{2}=0.44 \text { (only for } \mathrm{D}_{\mathrm{ap}}^{\mathrm{AP}} \text { ) } \\
\text { (linear) } \mathrm{R}^{2}<0.26\end{array}$ \\
\hline$P_{a p}$ & $\begin{array}{l}C_{s}^{\text {ad }} \\
C_{s}^{\text {tp }}\end{array}$ & $\begin{array}{l}\text { power (with } C_{s} \text { ) } \\
\text { power (with } C_{s} \text { ) }\end{array}$ & $\begin{array}{l}\mathrm{R}^{2}=0.19 \\
\mathrm{R}^{2}=0.27\end{array}$ \\
\hline $\mathrm{T}_{\mathrm{p}}$ & $\begin{array}{l}C_{s}^{\text {ad }} \\
C_{s}^{\text {tp }}\end{array}$ & $\begin{array}{l}\text { linear } \\
\text { linear }\end{array}$ & $\begin{array}{l}\mathrm{R}^{2}=0 \\
\mathrm{R}^{2}=0.95\end{array}$ \\
\hline $\mathrm{V}_{\mathrm{ap}}$ & $\begin{array}{l}\mathrm{C}_{\mathrm{s}}^{\mathrm{ad}} \\
\mathrm{C}_{\mathrm{s}}^{\mathrm{tp}} \\
\mathrm{D}_{\mathrm{ap}}^{\mathrm{GP}} \\
\mathrm{D}_{\mathrm{ap}}^{\mathrm{AP}}\end{array}$ & $\begin{array}{l}\text { power (with } C_{s} \text { ) } \\
\text { power }\left(\text { with } C_{s} \text { ) }\right. \\
\text { power } \\
\text { - }\end{array}$ & $\begin{array}{l}\mathrm{R}^{2}=0.28 \\
\mathrm{R}^{2}=0.54 \\
\mathrm{R}^{2}=0.70 \\
\text { (power) } \mathrm{R}^{2}=0.79\end{array}$ \\
\hline$\varnothing_{\text {core }}$ & $\begin{array}{l}\mathrm{D}_{\mathrm{ap}}^{\mathrm{GP}} \\
\mathrm{D}_{\mathrm{ap}}^{\mathrm{AP}} \\
\mathrm{V}_{\mathrm{ap}}\end{array}$ & $\begin{array}{l}\text { linear } \\
\text { linear } \\
\text { linear }\end{array}$ & $\begin{array}{l}\mathrm{R}^{2}=0.58 \\
\mathrm{R}^{2}=0 \\
\mathrm{R}^{2}=0.54\end{array}$ \\
\hline $\mathrm{PI}^{\mathrm{PT}}$ & $\begin{array}{l}\mathrm{V}_{\mathrm{ap}} \\
\mathrm{T}_{\mathrm{p}} \\
\mathrm{C}_{\mathrm{s}}^{\mathrm{tp}} \\
\emptyset_{\mathrm{core}} \\
\mathrm{D}_{\mathrm{ap}}^{\mathrm{GP}} \\
\mathrm{D}_{\mathrm{ap}}^{\mathrm{AP}} \\
\mathrm{P}_{\mathrm{ap}}\end{array}$ & power (with $C_{s}$ ) & $\begin{array}{l}\text { (linear) } R^{2}=0.60 \\
\text { (linear) } R^{2}=0.21 \\
\text { (linear) } R^{2}=0.40 \\
\text { (linear) } R^{2}=0.56 \\
\text { (linear) } R^{2}=0.55 \\
\text { (linear) } R^{2}=0.48 \\
\text { (power) } R^{2}=0.90\end{array}$ \\
\hline $\mathrm{PI}^{\mathrm{P}}$ & $\mathrm{V}_{\mathrm{ap}}$ & & (linear) $\mathrm{R}^{2}=0.30$ \\
\hline
\end{tabular}

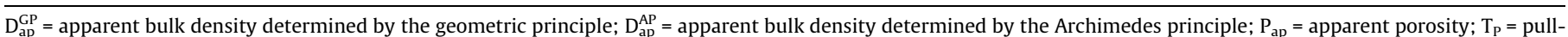

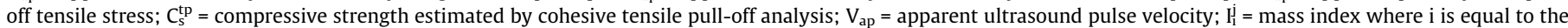

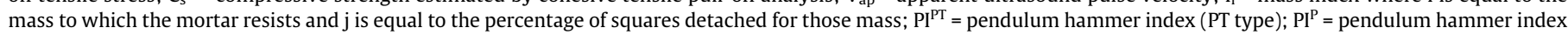

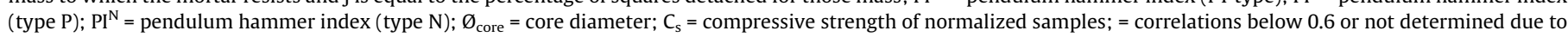
experimental constraints. 
Table 4

Synthesis of mechanical parameters and proposal of respective minimum and maximum limits for pre-dosed and conventional cement-based renders.

\begin{tabular}{|c|c|c|c|c|c|c|}
\hline $\begin{array}{l}\text { Measurement } \\
\text { parameters }\end{array}$ & $\begin{array}{l}\text { Min. } \\
\text { limit }\end{array}$ & $\begin{array}{l}\text { Reference } \\
\text { parameter }\end{array}$ & $\begin{array}{l}\text { Max. } \\
\text { limit }\end{array}$ & $\begin{array}{l}\text { Reference parameter } \\
\text { uncertainty* }\end{array}$ & Testing technique & $\begin{array}{l}\text { Verification method } \\
\text { type }\end{array}$ \\
\hline $\mathrm{T}_{\mathrm{P}}\left(\mathrm{N} / \mathrm{mm}^{2}\right)$ & 0.2 & $\geq 0.3$ & $\begin{array}{l}- \\
\text { I; II }\end{array}$ & $0^{\mathrm{a}}$ & Pull-off & quantitative \\
\hline $\mathrm{C}_{\mathrm{s}}^{\mathrm{tp}}\left(\mathrm{N} / \mathrm{mm}^{2}\right)$ & $\begin{array}{l}\geq 2.7 \\
\mathrm{I}\end{array}$ & 4.0 & $\overline{-}$ & $\geq 50 \% * *$ & Pull-off & quantitative \\
\hline $\mathrm{V}_{\mathrm{ap}}(\mathrm{km} / \mathrm{s})$ & $\begin{array}{l}\geq 2.7 \\
\mathrm{I}\end{array}$ & 3.3 & $\begin{array}{l}- \\
\text { II }\end{array}$ & $12 \%$ & Ultrasound pulse velocity & quantitative \\
\hline $\mathrm{PI}^{\mathrm{PT}}$ & $\geq 64$ & 75 & $\overline{-}$ & $\geq 50 \% * *$ & Pendulum hammer PT & quantitative \\
\hline $\mathrm{PI}^{\mathrm{P}}$ & $\begin{array}{l}\text { n/a } \\
\text { I. }\end{array}$ & $\mathrm{n} / \mathrm{d}$ & $\overline{-}$ & - & Pendulum hammer PT & quantitative \\
\hline $\mathrm{PI}^{\mathrm{N}}$ & $\begin{array}{l}\mathrm{n} / \mathrm{a} \\
\mathrm{I} .\end{array}$ & $\mathrm{n} / \mathrm{d}$ & $\overline{-}$ & - & Pendulum hammer $\mathrm{N}$ & quantitative \\
\hline$\emptyset_{\text {core }}(\mathrm{mm})$ & - & 13 & $<20$ & $23 \%$ & Martinet Baronnie & quantitative \\
\hline $\mathrm{I}_{1}^{\mathrm{j}}$ & $\begin{array}{l}>\mathrm{I}_{0} \\
\mathrm{I}\end{array}$ & $\mathrm{I}_{250}^{54}$ & $\begin{array}{l}\mathrm{I}_{1000}^{54} \\
\text { II }\end{array}$ & 1 scale $^{* * *}$ & Martinet Baronnie & quantitative \\
\hline $\mathrm{D}_{\mathrm{ap}}^{\mathrm{PG}}$ or $\mathrm{D}_{\mathrm{ap}}^{\mathrm{AP}}\left(\mathrm{kg} / \mathrm{m}^{3}\right)$ & $\geq 1300$ & 1550 & $\begin{array}{l}2000 \\
\text { II }\end{array}$ & $10 \%$ & $\begin{array}{l}\text { Hydrostatic weighing with saturation under } \\
\text { pressure }\end{array}$ & quantitative \\
\hline $\mathrm{P}_{\mathrm{ap}}(\%)$ & $\begin{array}{l}- \\
\text { II }\end{array}$ & 22 & $\begin{array}{l}30 \pm 5 \\
I\end{array}$ & $9 \%$ & & \\
\hline $\mathrm{C}_{\mathrm{s}}^{\mathrm{ad}}\left(\mathrm{N} / \mathrm{mm}^{2}\right)$ & $\geq 2.8$ & 5.2 & $\overline{-}$ & $\geq 50 \%$ & Compressive strength test & quantitative \\
\hline
\end{tabular}

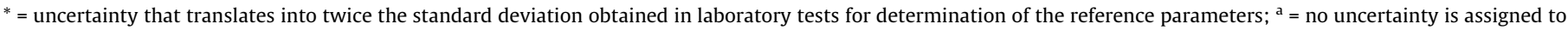

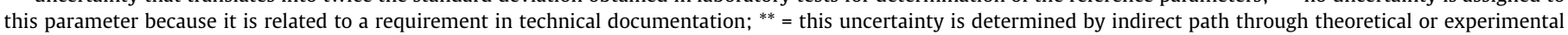

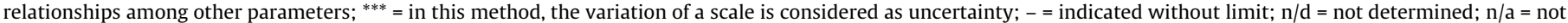

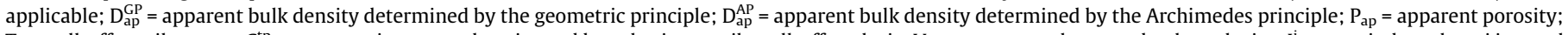

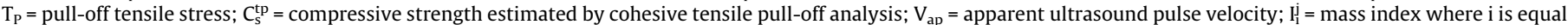

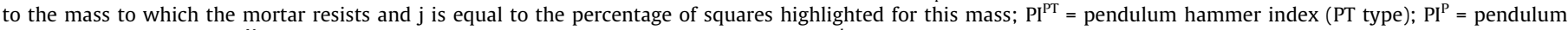
hammer index (type $\mathrm{P}) ; \mathrm{PI}^{\mathrm{N}}=$ pendulum hammer index (type $\left.\mathrm{N}\right) ; \emptyset_{\text {core }}=$ core diameter; $\mathrm{C}_{\mathrm{s}}^{\mathrm{ad}}=$ compressive strength after adhesion tests.

Table 5

Distribution of the parameters measured for the case studies, according to the reference parameters, proposed limits and maximum values.

\begin{tabular}{|c|c|c|c|c|c|}
\hline $\begin{array}{l}\text { Case studies } \\
\text { (renders) }\end{array}$ & \multicolumn{4}{|c|}{ Classification of the results obtained in each measurement parameter } & $\begin{array}{l}\text { Total of } \\
\text { parameters }\end{array}$ \\
\hline CS1 (MR) & $\mathrm{T}_{\mathrm{P}} ; \mathrm{PI}^{\mathrm{PT}} ; \emptyset_{\text {core }} ; \mathrm{i} ; \mathrm{V}_{\mathrm{ap}}$ & $\begin{array}{l}C_{\mathrm{s}}^{\mathrm{tp}} ; \mathrm{PI}^{\mathrm{PT}} ; \emptyset_{\text {core }} \mathrm{I}_{\mathrm{i}}^{\mathrm{j}} ; \mathrm{D}_{\mathrm{ap}}^{\mathrm{GP}} ; \mathrm{D}_{\mathrm{ap}}^{\mathrm{AP}} \\
\mathrm{C}_{\mathrm{s}}^{\mathrm{ad}}\end{array}$ & $P_{a p}$ & $\mathrm{~V}_{\mathrm{ap}}$ & 7 \\
\hline CS2 (PRP) & $\mathrm{T}_{\mathrm{P}} ; \mathrm{V}_{\mathrm{ap}} ; \emptyset_{\text {core }} ; \mathrm{I}_{1}^{\mathrm{j}}$ & $\mathrm{V}_{\mathrm{ap}} ; \mathrm{PI}^{\mathrm{PT}}$ & - & $\mathrm{V}_{\mathrm{ap} \text { (cracking) }}$ & 2 \\
\hline CS2 (DSC/DLC) & $\begin{array}{l}\mathrm{T}_{\mathrm{P}} ; \mathrm{C}_{\mathrm{s}}^{\mathrm{tp}} ; \mathrm{V}_{\mathrm{ap}} ; \mathrm{PI}^{\mathrm{PT}} ; \emptyset_{\text {core }} \mathrm{I}_{\mathrm{i}}^{\mathrm{j}} ; \mathrm{D}_{\mathrm{ap}}^{\mathrm{GP}} ; \mathrm{D}_{\mathrm{ap}}^{\mathrm{AP}} \\
\mathrm{P}_{\mathrm{ap}}\end{array}$ & $\mathrm{D}_{\mathrm{ap}}^{\mathrm{GP}}$ & $\mathrm{V}_{\mathrm{ap} \text { (pulverulescence); }} \mathrm{I}_{\mathrm{i}}^{\mathrm{j}}$ & $\mathrm{V}_{\mathrm{ap} \text { (cracking); }} \mathrm{C}_{\mathrm{s}}^{\mathrm{ad}}$ & 8 \\
\hline CS4 (MR) & - & $\mathrm{C}_{\mathrm{s}}^{\mathrm{ad}}$ & - & $\mathrm{T}_{\mathrm{P}} ; \mathrm{V}_{\mathrm{ap}}$ & 1 \\
\hline CS5 (MR) & $\emptyset_{\text {core; }} \mathrm{D}_{\mathrm{ap}}^{\mathrm{GP}} ; \mathrm{P}_{\mathrm{ap}} ; \mathrm{C}_{\mathrm{s}}^{\mathrm{ad}}$ & $\mathrm{D}_{\mathrm{ap}}^{\mathrm{GP}} ; \mathrm{D}_{\mathrm{ap}}^{\mathrm{AP}}$ & $\emptyset_{\text {core }}$ & $\begin{array}{l}\mathrm{T}_{\mathrm{P}} ; \mathrm{C}_{\mathrm{s}}^{\mathrm{tp}} ; \mathrm{V}_{\mathrm{ap}} \text { (pulverulescence); } \\
\mathrm{I}_{1}^{\mathrm{j}}\end{array}$ & 4 \\
\hline CS6 (DSC) & $\mathrm{T}_{\mathrm{P}} ; \mathrm{C}_{\mathrm{s}}^{\mathrm{tp}} ; \emptyset_{\text {core } ;} \mathrm{I}_{\mathrm{i}}^{\mathrm{j}} ; \mathrm{D}_{\mathrm{ap}}^{\mathrm{AP}} ; \mathrm{P}_{\mathrm{ap}} ; \mathrm{C}_{\mathrm{s}}^{\mathrm{ad}}$ & $\mathrm{D}_{\mathrm{ap}}^{\mathrm{GP}}$ & $\mathrm{C}_{\mathrm{s}}^{\mathrm{tp}} ; \mathrm{I}_{\mathrm{i}}^{\mathrm{j}}$ & $V_{\text {ap (pulverulescence) }}$ & 2 \\
\hline CS7 (PHR) & $\mathrm{T}_{\mathrm{P}} ; \mathrm{C}_{\mathrm{s}}^{\mathrm{tp}}$ & - & - & - & 4 \\
\hline CS8 (PHR) & $\mathrm{T}_{\mathrm{P}} ; \mathrm{C}_{\mathrm{S}}^{\mathrm{tp}}$ & - & $T_{P} ; C_{s}^{t p}$ & - & 4 \\
\hline CS9 (PHR) & $\mathrm{T}_{\mathrm{P}}$ & $C_{s}^{\mathrm{ad}}$ & - & - & 1 \\
\hline CS10 (DSC) & $\mathrm{D}_{\mathrm{ap}}^{\mathrm{AP}} ; \mathrm{P}_{\mathrm{ap}}$ & $\mathrm{D}_{\mathrm{ap}}^{\mathrm{GP}}$ & $C_{s}^{\mathrm{ad}}$ & $\mathrm{T}_{\mathrm{P}}$ & 1 \\
\hline CS11 (DSC) & - & - & $\mathrm{V}_{\mathrm{ap}}$ & $\mathrm{V}_{\mathrm{ap}} ; \mathrm{PI}^{\mathrm{PT}}$ & 4 \\
\hline CS12 (DSC) & - & - & $\mathrm{V}_{\mathrm{ap}} ; \mathrm{PI}^{\mathrm{PT}}$ & $\mathrm{V}_{\mathrm{ap}} ; \mathrm{PI}^{\mathrm{PT}}$ & 3 \\
\hline CS13 (DSC) & $\mathrm{V}_{\mathrm{ap}}$ & - & $\mathrm{V}_{\mathrm{ap}}$ & $\mathrm{PI}^{\mathrm{PT}}$ & 1 \\
\hline CS41 (MR) & $\mathrm{D}_{\mathrm{ap}}^{\mathrm{GP}} ; \mathrm{P}_{\mathrm{ap}} ; \mathrm{C}_{\mathrm{s}}^{\mathrm{ad}}$ & $\mathrm{D}_{\mathrm{ap}}^{\mathrm{GP}} ; \mathrm{D}_{\mathrm{ap}}^{\mathrm{AP}}$ & - & - & 1 \\
\hline
\end{tabular}

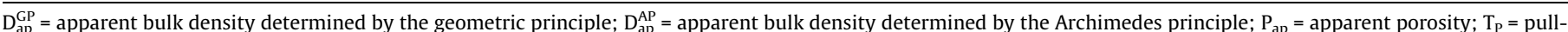

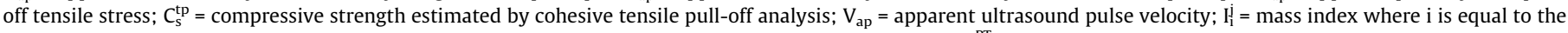

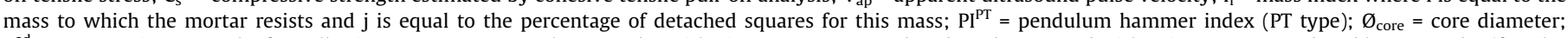

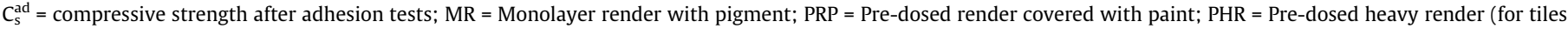
and stones); DSC = Dosed on site render (cement render); DLC = Dosed on site render (lime and cement render), - no value.

The proposed classification in Table 5 allows characterizing the mechanical performance. Some examples are highlighted:

- CS1 shows good adhesion, cohesive internal resistance and surface resistance. Some parameters indicate that this product presents a greater compactness/resistance than it would be expected. The low ultrasound pulse velocity may be related to the existence of visible micro-cracking in some areas. However, the invisible micro-cracks in other areas may affect the interior homogeneity of the applied render. In this case study, the apparent porosity presented high values that could lead to lower resistance. Nevertheless, by conjugating the other parameters, this hypothesis is not considered;

- CS2 presents good mechanical characteristics, which suffer a decrease in areas with anomalies, namely ultrasound pulse velocity in cracked areas and cut-off impact index in façades with superficial loss of cohesion (pulverulescence);

- CS5 shows some dispersion in the mechanical parameters' classification. However, there are obvious problems of adhesion and cohesive strength of the product, with poor surface resistance 
and internal heterogeneity. In this case study, the bulk density, the porosity and the compressive strength of samples presented better results. It is not possible to conclude to what extent the samples' degradation state affects the obtained results;

- CS6 presents good mechanical characteristics, with some resistance problems in the North facing façade, which had paint stripping and biological colonization. The apparent ultrasound pulse velocity has led to a lower average value in a zone subjected to continuous wetting for a long time (although it varies in height according to the variation of surface humidity of the rendered);

- CS11, CS12, and CS13 show low values of apparent ultrasound pulse velocity (due to cracking or other internal heterogeneity) and the pendulum hammer type PT index (with some blistering areas). According to these results, more tests would be necessary to prove the effective decrease of mechanical performance;

The results showed that there are differences between some mechanical parameters. In other words, some parameters are classified with the "green" colour and others with the "red" colour for the same case study, making it difficult to evaluate the in-situ mechanical performance. This can be improved if the reference parameters are the values declared by the manufacturer at the initial stage of application or if they result from previous inspections.

This analysis concluded that the same parameter may have different ratings, depending on whether it is evaluated in a visually good zone or with anomalies. Thus, the application of some techniques may complement the previous assessment of the surface condition in terms of the anomalies' nature and extent. Therefore, an "internal extension or in depth" factor may help to attribute the severity of the anomaly.

In some case studies, many parameters provided a homogeneous classification, so it would be more economical to choose the most reliable parameters. On the other hand, the analysis of two parameters was insufficient to evaluate the mechanical performance.

\subsection{Reliability indicators}

In general, the results show that the combined analysis of different parameters leads to improvement of knowledge about physical, chemical, and mechanical properties of rendered walls. Nevertheless, the results also conclude that the in-service diagnosis have several limitations. For example, the techniques are only applicable for accessible zones on the façade, the recommended testing numbers could not be controlled only by the façade' surface area, and most of the testing techniques spoil the render' aesthetic appearance, even those named non-destructive tests (ultrasound pulse velocity). The reliability indicators for each measurement parameter ranges from 1 to 5 , as presented in Table 6. As seen, none of the measurement parameters reached a score higher than 4 against the chosen criteria that ranged from 2 to 4 .

Although the global reliability indicator is useful (Fig. 2), it is also of interest to evaluate the measurement parameters in part according to each indicator in order to perceive the real limitations of each parameter (Fig. 3). The apparent ultrasound pulse velocity $\left(V_{a p}\right)$ allowed improving the in-service evaluation, but with sensitivity to some in-situ factors. For example, the façade' surface moisture can lead to overestimated $V_{a p}$ values due to the transitional time decrease of the ultrasound waves.

The apparent porosity of samples $\left(\mathrm{P}_{\mathrm{ap}}\right)$ allowed a better inservice characterization of the products, distinguishing the main groups of cementitious based mortars. However, the influence of some anomalies on $\mathrm{P}_{\mathrm{ap}}$ is not clear (e.g. superficial loss of cohesion -pulverulescence). Thus, this parameter is more relevant if the type of applied render is not known.

In case of the pull-off tensile stress $\left(T_{P}\right)$, the available reference in technical documentation may be insufficient to distinguish various types of mortar. However, "surveying" with this technique can minimize this disadvantage by observing the samples (with clear identification of unique zones and the constitution of the coating system in terms of layer numbers and thicknesses).

The diameter of core $\left(\emptyset_{\text {core }}\right)$ was useful in-service, but conditioned by the surface finishing type and the reference parameter variability (which can reach $26 \%$ ).

The pendulum hammer index (PI) was a useful parameter in reducing the variability of results obtained with several measurements (mappings) since this technique is non-destructive. However, the influence of in-service conditions (e.g. support and application conditions) on its results was verified. Therefore, the proposed reference parameter was not obtained in the laboratory, but determined through relations with others parameters $\left(\mathrm{R}^{2}>0.60\right)$.

The apparent density by hydrostatic weighing (Dap ${ }^{\mathrm{AP}}$ ) had a reference parameter with low uncertainty. However, this did not lead to obtaining relevant in-service information in terms of product type and relation with the anomalies, probably due to the inservice factors.

The mass index $\left(\mathrm{I}_{\mathrm{i}}^{\mathrm{j}}\right)$ is a qualitative parameter added little information in relation to the surface resistance characterized by the

Table 6

Reliability indicators for the measurement parameters' in-service classification.

\begin{tabular}{|c|c|c|c|c|c|}
\hline \multirow[t]{2}{*}{ Index } & \multicolumn{5}{|l|}{ Rating scale of reliability indicators } \\
\hline & 1 & 2 & 3 & 4 & 5 \\
\hline $\mathrm{I}_{\mathrm{f} 1}$ & $>50 \%$ & $31-50 \%$ & $16-30 \%$ & $6-15 \%$ & $\leq 5 \%$ \\
\hline $\mathrm{I}_{\mathrm{f} 2}$ & Interval & - & Qualitative & - & Quantitative \\
\hline $\mathrm{I}_{\mathrm{f} 3}$ & Insufficient & - & May be sufficient in some cases & - & Sufficient \\
\hline $\mathrm{I}_{\mathrm{f} 4}$ & $\begin{array}{l}\text { Significant sensitivity, with some incoherent } \\
\text { values }\end{array}$ & - & Sensitivity in some cases & - & Not sensitive \\
\hline $\mathrm{I}_{\mathrm{f} 5}$ & $\begin{array}{l}\text { Does not contribute or its relation with relevant } \\
\text { anomalies is not clear }\end{array}$ & $\begin{array}{l}\text { Characterizing } 1 \\
\text { anomaly }\end{array}$ & Characterizing 2 anomalies & & $\begin{array}{l}\text { Characterizing } \geq 3 \\
\text { anomalies }\end{array}$ \\
\hline $\mathrm{I}_{\mathrm{f} 6}$ & $>50 \%$ & $31-50 \%$ & $21-30 \%$ & $11-20 \%$ & $\leq 10 \%$ \\
\hline $\mathrm{I}_{\mathrm{f} 7}$ & 1 measure & 2 measures & 3 measures & $\begin{array}{l}5 \\
\text { measures }\end{array}$ & $\geq 6$ measures \\
\hline
\end{tabular}

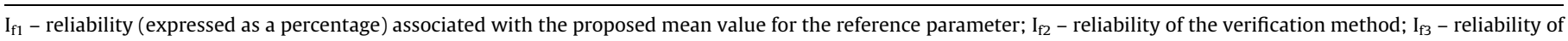

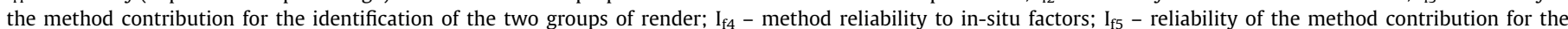

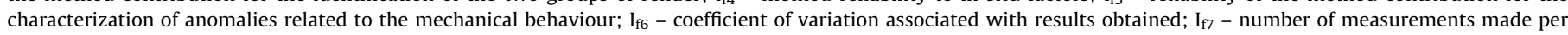
study or case study. 


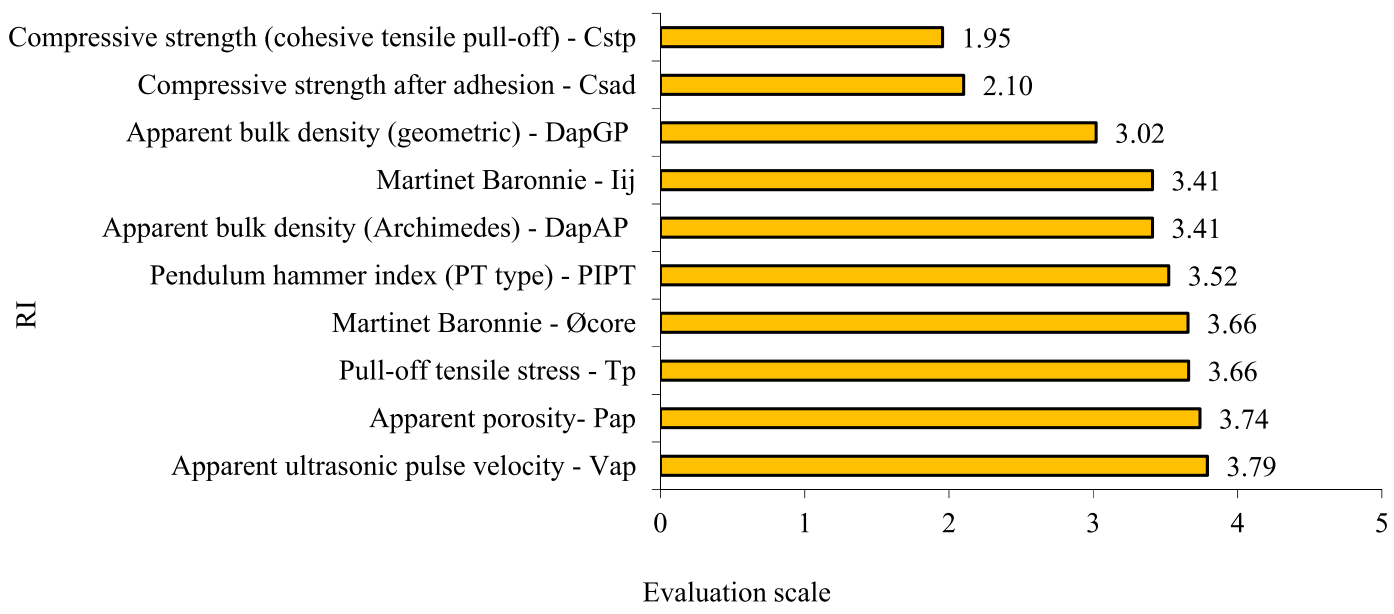

Fig. 2. Global reliability indicator for each mechanical measurement parameter.

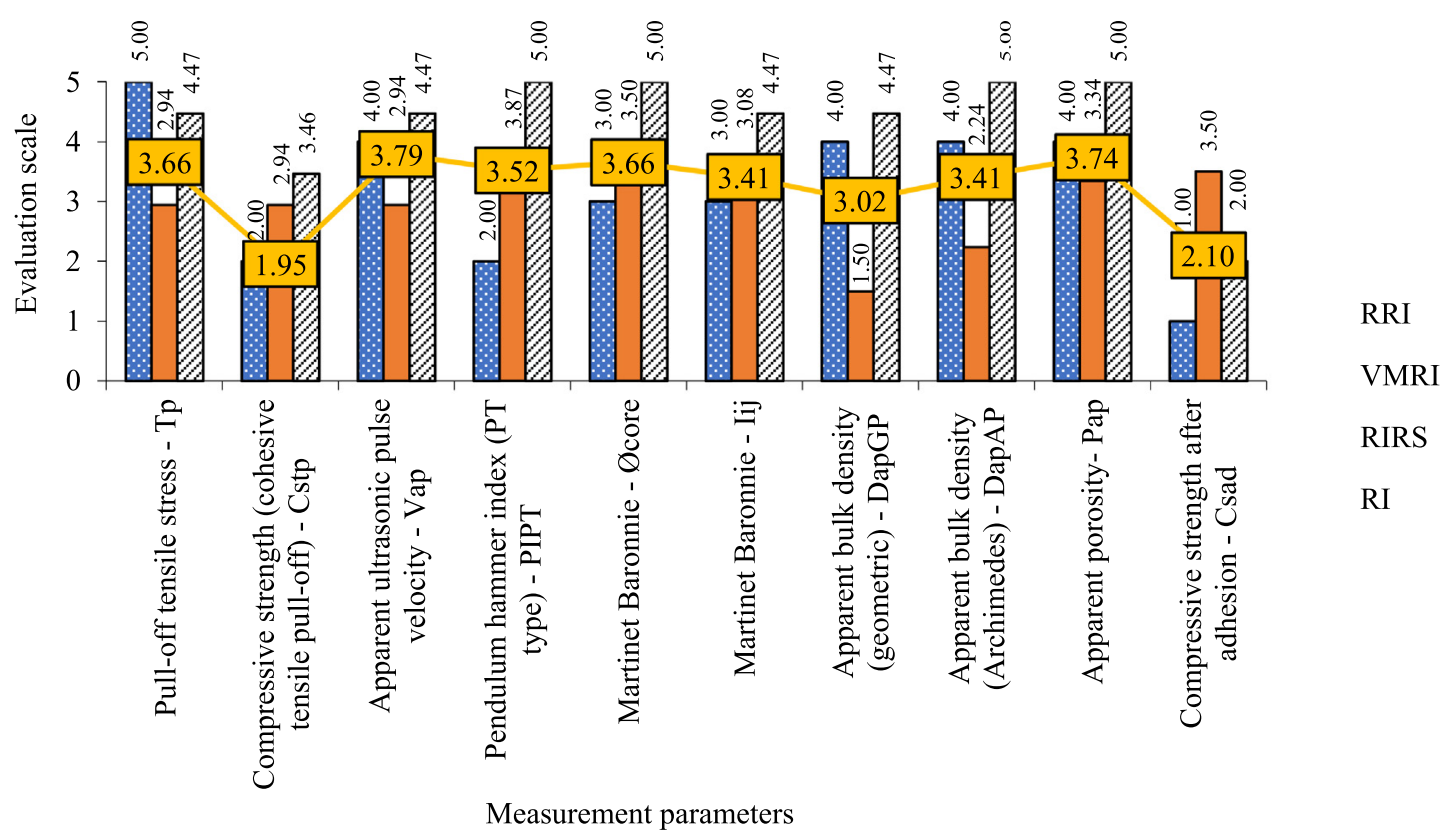

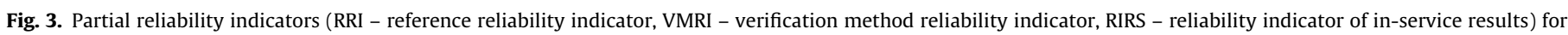
each mechanical in-service measurement.

diameter of the core, although theoretically it is possible to evaluate higher impact energies. The adoption of indexes with defining the damaged square' numbers improved the collected in-service information. However, the finishing type significantly influenced the results.

The bulk density by the geometric principle ( Dap $^{\mathrm{GP}}$ ) is similar to the parameter determined by the principle of Archimedes (Dap ${ }^{\mathrm{AP}}$ ). However, in-service results have led to very high values due to external factors. An example would be the irregularity or internal heterogeneity of samples collected from conventional products.

The compressive strength of samples after adhesion $\left(\mathrm{Cs}^{\text {ad }}\right)$ presented the main constraint in the uncertainty of the reference parameter, which reached $50 \%$ in the laboratory results. In addition, the compression test depends on the degraded state of the samples, the sensitivity of the operator, the type of testing machine, and the thickness of the samples. However, in spite of these results, the determination of the compressive strength is an essential parameter in the on site characterization of the renders.

For the cohesion compressive strength from pull-off test $\left(\mathrm{Cs}^{\mathrm{tp}}\right)$, despite the disadvantage mentioned for $\mathrm{Cs}^{\text {ad }}$ in relation to the reference parameter uncertainty, $\mathrm{Cs}^{\text {tp }}$ parameter also has the following disadvantages: it cannot always be used since it results from the evaluation of a mostly cohesive break in the pull-off test; whereby it depends on the uncertainty associated with the system, such as the type of support or conditions during the inspection. However, this parameter proved to be important to complement the interpretation of tensile strength test.

Similarly, to the analysis of mechanical parameters, the characterization of physical-chemical reliability indicators (RRI, VMRI, and RIRS) were carried out but not presented here.

\section{Mechanical render performance evaluation based on reliability indicators}

Following the literature review carried out in the introduction (Section 1), it was concluded that the mechanical performance in-service characteristics to be checked for façade renders are the internal or cohesive resistance, deformation capacity, adhesion to support and surface resistance. On the other hand, a number of 
Table 7

Measurement parameters relevant to the mechanical behaviour of applied render.

\begin{tabular}{|c|c|c|c|c|c|c|}
\hline \multirow[t]{2}{*}{ Verification methods } & \multirow[t]{2}{*}{ In-service measurement parameters } & \multirow[t]{2}{*}{ Reliability indicator } & \multicolumn{4}{|c|}{ In-service mechanical performance } \\
\hline & & & $\mathrm{CP} 1$ & $\mathrm{CP} 2$ & $\mathrm{CP} 3$ & CP4 \\
\hline \multirow[t]{2}{*}{ Hydrostatic weighing } & $\mathrm{D}_{\mathrm{ap}}^{\mathrm{AP}}\left(\mathrm{kg} / \mathrm{m}^{3}\right)$ & 3.41 & 0 & $\bullet$ & ○ & $\bullet$ \\
\hline & $\mathrm{P}_{\mathrm{ap}}(\%)$ & 3.74 & $\bullet$ & $\bullet$ & $\bullet$ & $\bullet$ \\
\hline \multirow[t]{2}{*}{ Pull-off } & $\mathrm{T}_{\mathrm{p}}\left(\mathrm{N} / \mathrm{mm}^{2}\right)$ & 3.66 & 0 & $\mathrm{O}$ & $\bullet$ & - \\
\hline & $\mathrm{C}_{\mathrm{s}}^{\mathrm{tp}}\left(\mathrm{N} / \mathrm{mm}^{2}\right)$ & 1.95 & $\bullet$ & $\mathrm{O}$ & $\bullet$ & ○ \\
\hline Compressive strength & $\mathrm{C}_{\mathrm{s}}^{\mathrm{ad}}\left(\mathrm{N} / \mathrm{mm}^{2}\right)$ & 2.10 & - & 0 & 0 & 0 \\
\hline Ultrasound pulse velocity & $\mathrm{V}_{\mathrm{ap}}(\mathrm{km} / \mathrm{s})$ & 3.79 & O & $\bullet$ & 0 & $\mathrm{O}$ \\
\hline Pendulum hammer & $\mathrm{PI}^{\mathrm{PT}}$ & 3.52 & - & $\bigcirc$ & $\mathrm{O}$ & - \\
\hline \multirow[t]{4}{*}{ Martinet Baronnie } & $\emptyset_{\text {core }}(\mathrm{mm})$ & 3.66 & $\bigcirc$ & $\mathrm{O}$ & - & $\bullet$ \\
\hline & $\mathrm{I}_{1}^{\mathrm{j}}$ & 3.41 & $\mathrm{O}$ & $\mathrm{O}$ & - & $\bullet$ \\
\hline & $\mathrm{I}_{\mathrm{S}}$ & $\mathrm{n} / \mathrm{d}$ & ○ & - & - & $\bullet$ \\
\hline & $\mathrm{I}_{\mathrm{A}}$ & $\mathrm{n} / \mathrm{d}$ & $\bigcirc$ & - & - & • \\
\hline
\end{tabular}

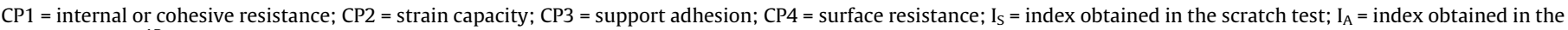

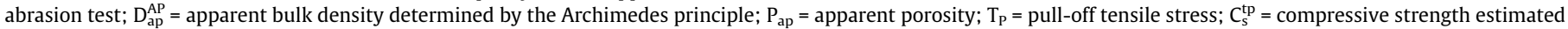

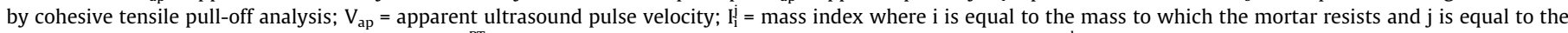

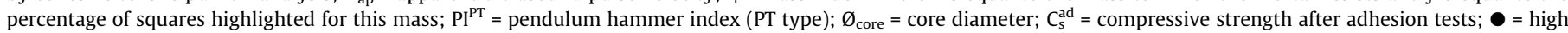
correlation; $\bigcirc=$ mean correlation; - = without correlation or low correlation. $\mathrm{n} / \mathrm{d}=$ not determined.

measurement parameters have been identified for the available verification methods, which in most cases do not establish a direct and unambiguous relationship with each of the mentioned performance characteristics. In other words, two situations may occur: (1) a parameter can be an indirect measure of one or more performance characteristics, such as apparent density or apparent porosity; or (2) a performance characteristic may not have a sufficient characterization with the measurement parameters studied. The deformation capacity characteristic also requires in-service measurements after application in the hardening phase where the main movements in the mortar occur, which can condition the performance of the render in the subsequent phase. Despite the mentioned limitations, a selection matrix is proposed that qualitatively identifies the set of parameters that contribute to indirectly analyse the four characteristics and performance relevant to the mechanical behaviour of the renders applied on façades (Table 7).

From the several case studies, it was concluded that the analysis of more than one parameter significantly complemented the diagnosis, minimizing other constraints inherent in an in-situ evaluation, such as uncertainty of verification methods or constraints associated with sampling. The analysis of the mechanical behaviour shall account for the measurement parameters determined for zones without anomalies. The conformity of these parameters can be made in two ways: 1) there are elements in the collected information that identify and characterize the applied render; 2) there is no information available, and it is necessary to identify to which group the render belongs to (measure, for example, the apparent porosity).

The same approach was carried out for physical-chemical performance characteristics but not presented here in order to limit the length of the paper.

\section{Conclusions}

In this study, reliability indicators are proposed based on experimental data (in-service parameters) from testing 98 surfaces. This experimental data provides relevant information for in-service performance evaluation but several restraints, for example, parameters with high uncertainty verification methods associated; and others that, despite good results in the laboratory, were not conclusive after the analysis of the case studies. In fact, aspects related to in-service degradation, which were not accounted for in the laboratory tests, appear to be decisive for these differences. However, the study of real cases allowed the identification of other new relationships between parameters and between these and existing anomalies.

It is consensual that in-situ techniques are useful, because of their application simplicity and the reduced costs of equipment. However, they present some limitations, in addition to those existing in terms of means of access, for example some methods were not suitable for all types of renders; and the combined analysis of several parameters obtained with the same verification method or with different methods allowed a better interpretation of the results.

In conclusion, in spite of the advantage in the analysis of more than one parameter and of using more than one in-situ technique, there were some discrepancies in some cases leading to different performance evaluations. For example, mechanical parameters, when analysed individually, led to different conclusions, such as a mortar being able to be evaluated with good or poor mechanical strength. For these reasons, the main purpose of this paper was to discuss the application of reliability parameters to help evaluate the in-service performance of renders. Thus, three uncertainty factors were identified as relevant for these differences: i) uncertainty in the reference parameter; ii) uncertainty in the verification method; and iii) uncertainty in the obtained results (in terms of coefficient of variation and number of tests). In this regard, an overall reliability indicator has been proposed that includes criteria related to the previous factors and that supports the inspector in choosing the most reliable parameters for an inspection.

From the application of the overall reliability indicator to the measurement parameters, it was found that the ultrasound pulse velocity and the apparent porosity led to a higher score. In this context, it is important to highlight that the apparent porosity allows the identification of the different mortars types (relevant aspect when the applied renders' characteristics are not known), as well as establishing relations with other measurement parameters.

The measurement parameters do not establish a univocal relation with each of the performance characteristics, given their interrelationship. However, a greater or lesser contribution of each parameter was proposed for each of the performance characteristics. This facilitated the conformity assessment by performance characteristics, providing a basis for future studies with other measurement parameters.

Future studies are expected to assess compliance criteria, limits and tolerances proposed by analysing a greater number of cases, with different types of degradation and conditions in-service, in which a computer application and numerical analysis may simplify the processing of information and the interpretation of the in-situ experimental data. 


\section{Declaration of Competing Interest}

The authors declare that they have no known competing financial interests or personal relationships that could have appeared to influence the work reported in this paper.

\section{Acknowledgements}

The authors wish to thank CERIS - IST research centre and FCT (Foundation for Science and Technology).

\section{References}

[1] E. Biseniece, R. Freimanis, R. Purvins, A. Gravelsins, A. Pumpurs, A. Blumberga, Study of hygrothermal processes in external walls with internal insulation, Environmental and Climate Technologies 22 (2018) 22-41.

[2] E.V. Schmid, Exterior Durability of Organic Coatings, FMJ International Publications Limited, UK, 1988.

[3] D. Marshall, D. Worthing, R. Heath, External Rendering, second ed., Estates Gazette, 2003.

[4] L. Addleson, C. Rice, Performance of materials in Buildings - A Study of the Principles and Agencies of Change, Butterworth-Heinemann, Oxford, 1991.

[5] H. Künzel, Criteria defining rain protecting external rendering systems, Energy Procedia 78 (2015) 2524-2529.

[6] J. Pinto, S. Cunha, N. Soares, E. Soares, V.M.C.F. Cunha, D. Ferreira, A. Sá, Earthbased render of partition walls - an experimental work contribution, International Journal of Architectural Heritage 11 (2) (2015) 185-197.

[7] H. Carasek, F.H. Vaz, O. Cascudo, Statistical analysis of test methods to evaluate rendering surface properties, Ambiente Construído 18 (2) (2018) 87-105.

[8] I.M. Shohet, M. Puterman, E. Gilboa, Deterioration patterns of building cladding components for maintenance management, Construction Management and Economics 20 (2002) 305-314.

[9] A. Silva, L.C. Neves, P.L. Gaspar, J. de Brito, Probabilistic transition of condition: render facades, Building Research \& Information 44 (3) (2016) 301-318.

[10] EOTA, Determination of impact resistance of panels and panel assemblies, European Organization for Technical Approvals, TR001, 2003.

[11] PSA, Defects in Buildings, HMSO publications, London, UK, 1989.

[12] BSI, Guide to Durability of Buildings and Building Elements, Products and Components, British Standard Institute, 2003.

[13] P. Parnham, Prevention of Premature Staining of New Buildings, E\&FN Spon, London, 1997.

[14] BRE, BRE Digest 370 - Control of lichens, moulds and similar growths, BRE Digest 370, BRE, UK, 1992.

[15] ISO, Vertical Building Elements - Impact Resistance - Impact Bodies and General Test Procedures, Switzerland, International Organization for Standardization, 1988.

[16] M. Rikey, A. Cotgrave, The context of maintenance, in: Macmillan Palgrave (ed.), Construction Technology. The Technology of Refurbishment and Maintenance, vol. 3, New York, 2005, pp. 50-56.

[17] R.P. Thorogood, Resistance of external walls to impacts from hard objects: research leading to requirements and an assessment technique, in: Performance Concept in Building, Lisbon, March-April, 1982.
[18] I. Flores-Colen, L. Silva, J. de Brito, P.V. de Freitas, In-service parameters from façade rendering mortars, Structural Survey 28 (1) (2010) 17-27.

[19] I. Flores-Colen, J. de Brito, P.V. de Freitas, On-site performance assessment of rendering façades for predictive maintenance, Structural Survey 29 (2) (2011) $133-146$.

[20] N.M.M. Ramos, M.L. Simões, J.M.P.Q. Delgado, V.P. de Freitas, Reliability of the pull-off test for in situ evaluation of adhesion strength, Construction and Building Materials 31 (2012) 86-93.

[21] E. Barreira, V.P. de Freitas, External thermal insulation composite systems: critical parameters for surface hygrothermal behaviour, Advances in Materials Science and Engineering (2014). 16p 650752.

[22] I. Flores-Colen, J. de Brito, V.P. de Freitas, Using ultrasound for in-service assessment of rendered walls, Experimental Techniques 40 (4) (2016) 12031214.

[23] I. Flores-Colen, L. Silva, J. de Brito, V.P. de Freitas, Drying index for in-service physical performance assessment of renders, Construction and Building Materials 112 (2016) 1101-1109.

[24] L. Silva, I. Flores-Colen, N. Vieira, A.B. Timmons, Natural ageing tests to study in-service different façade solutions-ETICS and premixed one-coat rendered walls, Journal of Civil Engineering and Architecture 10 (2016) 667-674.

[25] P.C. Guterres, L.P. de Oliveira, Behaviour of rendering mortar for rehabilitation of buildings subjected to rising damp, Journal of Civil Engineering and Architecture 11 (2017) 342-347.

[26] L. Olsson, Rain resistance of façades with façade details: A summary of three field and laboratory studies, Journal of Building Physics 41 (6) (2017) 521-532.

[27] L. Ollson, Rain resistance of façades with façade details: a summary of three field and laboratory studies, Building Physics 41 (6) (2018) 521-532.

[28] L.R. Valero, V.F. Sasso, E.P. Vicioso, In situ assessment of superficial moisture condition in façades of historic building using non-destructive techniques, Case Studies in Construction Materials 10 (2019) e00228.

[29] RICS, BMI Life expectancy of building components - Surveyors' experiences of buildings in use. A practical guide, Royal Institution of Chartered Surveyors, Building Cost Information Service, London, 2006.

[30] ISO 14040:2006, Environmental management - Life cycle assessment Principles and framework.

[31] A. Menezes, M.G. Gomes, I. Flores-Colen, In situ assessment of physical performance and degradation analysis of rendering walls, Construction Building Materials 30 (2015) 283-292.

[32] E. Sassine, A practical method for in-situ thermal characterization of walls, Case Studies in Thermal Engineering 8 (2016) 84-93.

[33] R. Duarte, I. Flores-Colen, J. de Brito, A. Hawreen, Variability of in-situ testing in wall coating systems - Karsten tube and moisture meter techniques, Journal of Building Engineering 27 (2020) 100998.

[34] J. Galvão, R. Duarte, I. Flores-Colen, J. de Brito, A. Hawreen, Non-destructive mechanical and physical in-situ testing of rendered walls under natural exposure, Construction and Building Materials 230 (2020) 116838.

[35] I. Flores-Colen, L. Silva, J, de Brito, V. de Freitas, In-service parameters from façade rendering mortars: bulk density and open porosity determined from samples collected in situ, Structural Survey 28 (1) (2010) 17-27.

[36] J. Galvão, I. Flores-Colen, J. de Brito, M.R. Veiga, Variability of in-situ testing on rendered walls in natural ageing conditions - rebound hammer and ultrasound techniques, Construction and Building Materials 170 (10) (2018) $167-181$.

[37] C. Grøn, J.A. Falkenberg, J.S. Andersen, M. Børresen, A. Pettersen, S. Nilsson, K. Håkansson, J. Laiho, Quality control manual for field measurements (NT TR 581), NT technical reports, Environment, 2005. 